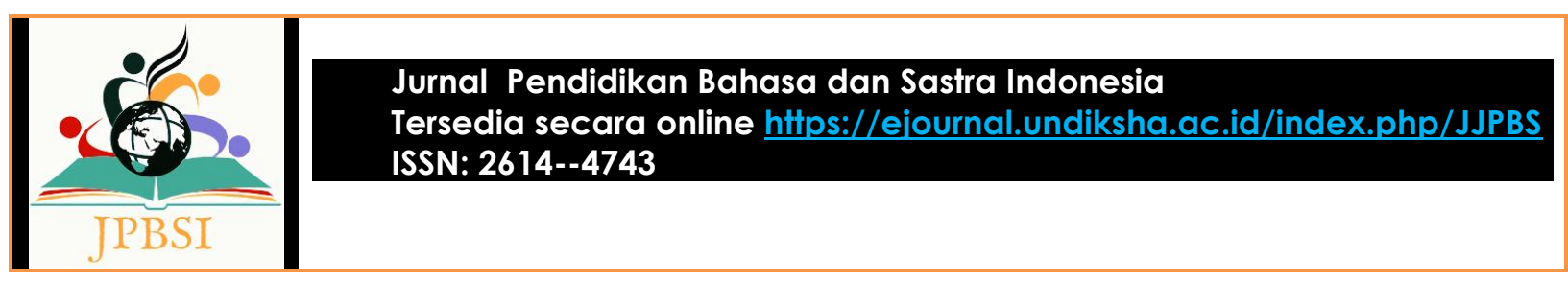

\title{
KEMAMPUAN MENULIS SURAT DINAS DAN SURAT LAMARAN PEKERJAAN BERPANDUKAN MODUL PADA MAHASISWA S-1 PENDIDIKAN BAHASA INDONESIA FKIP UNIVERSITAS TANJUNGPURA
}

\author{
Sesilia Seli ${ }^{1}$, Zeno Anggih ${ }^{2}$ \\ ${ }^{1,2}$ Program Studi Pendidikan Bahasan Indonesia Universitas Tanjungpura \\ Pontianak, Kalimantan Barat, Indonesia
}

Surel: sesilia.seli@fkip.untan.ac.id ${ }^{1}$, zenoanggih10@gmail.com ${ }^{2}$

\begin{tabular}{|c|c|}
\hline \multicolumn{2}{|r|}{ Abstrak } \\
\hline $\begin{array}{l}\text { Kata Kunci: } \\
\text { Kemampuan Menulis; } \\
\text { Modul; Surat Dinas; } \\
\text { Surat Lamaran } \\
\text { Pekerjaan. }\end{array}$ & $\begin{array}{l}\text { Keterampilan menulis surat dinas dan surat lamaran pekerjaan perlu dilakukan dalam } \\
\text { rangka meningkatkan pengetahuan dan keterampilan dalam bidang korespondensi } \\
\text { sehingga mahasiswa tidak kebingungan untuk mengajukan lamaran pekerjaan kepada } \\
\text { berbagai instansi yang mereka minati. Menyikapi hal tersebut, maka tujuan penelitian } \\
\text { ini adalah mendeskripsikan kebermanfaatan modul, kemampuan menulis } \\
\text { surat dinas; kemampuan menulis surat lamaran; dan kemampuan dalam } \\
\text { menulis surat dinas dan surat lamaran pekerjaan berpandukan modul pada } \\
\text { mahasiswa S-1 Pendidikan Bahasa Indonesia FKIP Universitas Tanjungpura } \\
\text { Penelitian ini menggunakan metode deskriptif kuantitatif, teknik survey melalui } \\
\text { google form ,dan teknik pengukuran. Hasil penelitian ini menujukkan bahwa } 65,7 \% \\
\text { responden mengatakan bahwa modul yang digunakan dalam menulis surat dinas dan } \\
\text { surat lamaran pekerjaan sangat bermanfaat; rata-rata kemampuan menulis surat dinas } \\
\text { sebesar } 83,6 \text {, berada dalam rentangan } 76-85 \text { dengan kategori baik; rata-rata } \\
\text { kemampuan mahasiswa menulis surat lamaran pekerjaan sebesar } 85,4 \text {, berada pada } \\
\text { rentangan } 76-85 \text { dengan kategori baik; dan rata-rata kemampuan mahasiswa menulis } \\
\text { surat dinas dan surat lamaran pekerjaan sebesar } 84,5 \text {, berada dalam rentangan } 76-85 \\
\text { dengan kategori baik. }\end{array}$ \\
\hline \multicolumn{2}{|r|}{ Abstract } \\
\hline $\begin{array}{l}\text { Keywords: } \\
\text { Writing Skills; } \\
\text { Modules, Official } \\
\text { Letters; Job } \\
\text { Application Letters, }\end{array}$ & $\begin{array}{l}\text { Skills in writing official letters and job application letters need to be done in order to } \\
\text { improve knowledge and skills in the field of correspondence so that students are not } \\
\text { confused about submitting job applications to various agencies they are interested in. } \\
\text { In response to this, the purpose of this study is to describe the usefulness of the } \\
\text { module, the ability to write official letters; the ability to write a cover letter; and the } \\
\text { ability to write official letters and job application letters based on modules for } \\
\text { undergraduate students of Indonesian Language Education FKIP Tanjungpura } \\
\text { University. This research uses quantitative descriptive methods, survey techniques via } \\
\text { google form, and measurement techniques. The results of this study indicate that } \\
65.7 \% \text { of respondents said that the modules used in writing official letters and job } \\
\text { application letters were very useful; the average ability to write official letters is } 83.6 \text {, } \\
\text { in the range of } 76-85 \text { with a good category; the average ability of students to write a } \\
\text { job application letter is } 85.4 \text {, in the range of } 76-85 \text { with a good category; and the } \\
\text { average ability of students to write official letters and job applications is } 84.5 \text {, in the } \\
\text { range of 76-85 with good categories. }\end{array}$ \\
\hline $\begin{array}{l}\text { Diterima/direview/ } \\
\text { dipublikasi }\end{array}$ & 27 Juli 2021/ 21 Agustus 2021/ 30 September 2021 \\
\hline
\end{tabular}




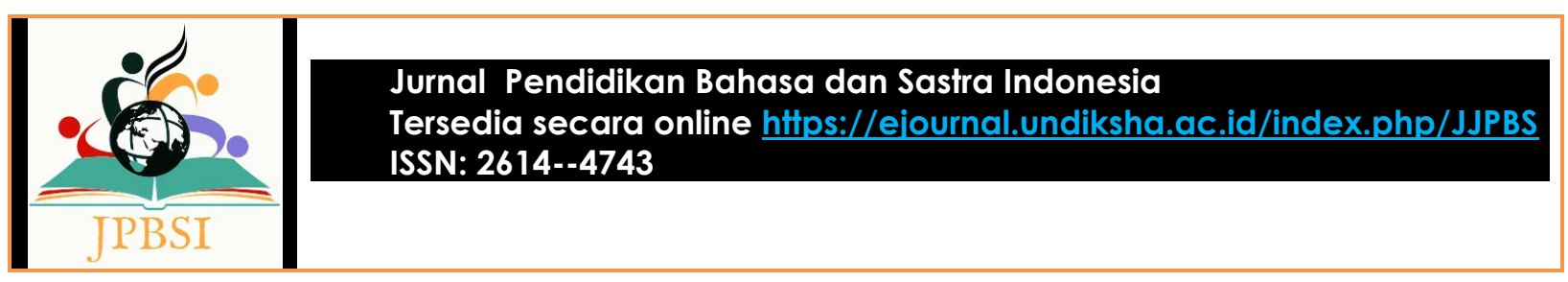

PENDAHULUAN

Menulis surat dinas dan surat lamaran pekerjaan merupakan keterampilan produktif dalam berbahasa. Kedua jenis surat tersebut perlu dilatihkan kepada para mahasiswa dengan tujuan untuk membekali mereka memasuki dunia kerja atau dunia usaha. Disadari juga tidak semua sarjana Pendidikan Bahasa Indonesia akan bekerja sebagai guru/dosen. Beberapa almuni bahkan bekerja sebagai jurnalis, politisi, pengusaha, penerjemah, pewara, penggiat seni, tenaga administrasi, dll.

Mencermati kebutuhan praktis tersebut dipandang perlu diberikan tambahan pengetahuan dan keterampilan melalui pelatihan yang berkaitan dengan penulisan surat-menyurat kepada mahasiswa semester 7 Prodi S-1 Pendidikan Bahasa Indonesia dengan pertimbangan bahwa sebentar lagi $( \pm 2$ semester) para mahasiswa akan me-nyelesaikan studinya dan akan memasuki dunia kerja. Pada saat itulah mereka memerlukan pengetahuan yang cukup dan keterampilan yang memadai untuk menulis surat lamaran pekerjaan dan berbagai surat dinas lainnya. Oleh sebab itu, pelatihan tentang penulisan surat dinas dan surat lamaran pekerjaan memang perlu dilakukan dalam rangka menambah pengetahuan dan keterampilan dalam bidang korespondensi.

Sarawati (2015:11) mengatakan bahwa surat dinas adalah segala bentuk surat resmi yang digunakan dalam hubungannya dengan kegiatan-kegiatan kedinasan (lembaga atau instansi pemerintah). Menurut Suprapto (2004:3)surat dinas adalah surat yang ditulis untuk kepentingan atau menyangkut masalah lembaga, organisasi, instansi, jawatan, perusahaan, dan sebagainya. Menurut Soedjito dan Solichin, (2016:14) surat dinas adalah surat yang berisi masalah kedinasan atau administrasi pemerintah. Surat dinas hanya dibuat oleh instansi pemerintah dan dapat dikirimkan kepada semua pihak yang memiliki hubungan dengan instansi tersebut.

Surat dinas atau surat resmi merupakan surat yang dipergunakan untuk kepentingan yang bersifat resmi, baik yang ditulis perseorangan, instansi, lembaga maupun organisasi (Supriyana dkk., 2015:7). Rohmadi (2014:114) juga mengungkapkan bahwa surat resmi atau surat dinas ialah surat yang digunakan dan dikirim oleh instansi atau masyarakat yang sifatnya resmi, sedangkan menurut (Nadia dan Sugiharti, 2018:187) surat dinas merupakan surat yang berisi hal penting yang berkenaan dengan administrasi pemerintahan dan pembangunan. Namun tidak dapat dibantah bahwa instansi swasta juga membuat surat-surat dinas untuk kepentingan pengelolaan organisasinya, seperti penulisan undangan, surat keterang-an, berita acara, surat pemberitahuan, pengumuman, edaran, surat tugas dll.

Berdasarkan beberapa pendapat tersebut dapat disimpulkan bahwa penulisan surat dinas merupakan salah satu kegiatan dalam administrasi yang dapat membantu kelancaran aktivitas bidang administrasi. Oleh karena itu, penulisan surat dinas sangat penting untuk men-dukung proses kerja administrasi. Penulisan surat dinas sangat diperlukan di dalam sebuah lembaga sebagai sumber data atau informasi yang bermanfaat untuk kemajuan lembaga tersebut. Surat sebagai sarana komunikasi tertulis yang dapat menunjang tercapainya tujuan lembaga.

Menurut Meliagustin et al. (2019:294) struktur surat dinas meliputi kop surat, tanggal surat, nomor surat, lampiran, perihal, alamat, salam pembuka, isi surat, salam penutup, nama dan tanda tangan dan tembusan. Menurut Hasriati, T dkk. (2017:236) adapun penggunaan bahasa pada surat dinas yaitu sebagai berikut: (1) pilihan kata sapaan bersifat formal; (2) bahasa yang jelas; (3) menggunakan bahasa formal; dan (4) Pemilihan kata baku.

Isi surat dinas berkaitan dengan topik kedinasan, seperti undangan rapat, per-mohonan maaf suatu instansi kepada orang/instansi/perusahaan, lamaran pekerja-an, surat permintaan izin tidak masuk, izin menggunakan tempat, dan sebagainya. Surat dinas hanya boleh ditulis oleh sebuah instansi kepada instansi lain atau individu. Penulisan surat dinas tergantung pada kaidah kebahasaan dan menggunakan bahasa formal (Hasriati, dkk. 2017:50). Menurut Finoza (1997:6-7) kriteria dan 


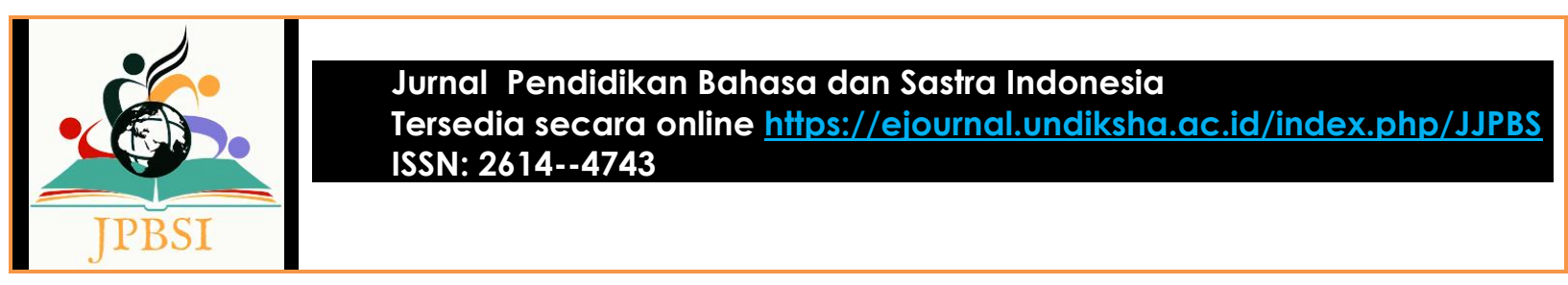

ciri umum surat yang baik adalah: menggunakan kertas surat yang tepat dari segi ukuran, jenis, dan warna sesuai dengan surat yang akan ditulis; menggunakan bentuk surat yang standar; menggunakan bahasa yang baku; menggunakan bahasa yang jelas: dan menggunakan bahasa yang sopan dan hormat. Berdasarkan berbagai teori yang dirujuk tersebut, indikator yang digunakan untuk menilai keberhasilan mahasiswa menulis surat dinas meliputi: (a) ketepatan penggunaan bentuk surat; (b) ketepatan penulisan bagian surat; (c) ketepatan isi surat; (d) ketepatan kebahasaan surat (diksi, kalimat, dan ejaan).

Menurut Sotyaningrum (2008:237) surat lamaran pekerjaan adalah surat dari pencari kerja kepada calon pemberi kerja yang berisi permohonan untuk mengisi lowongan jabatan yang tersedia. Surat lamaran pekerjaan berisi permohonan untuk bekerja di suatu lembaga, perusaha-an, atau perseoran terbatas (PT) yang pada umumnya memiliki bagian-bagian berisi identitas diri, jasa yang dapat dilakukan, pendidikan, hingga keterangan keahlian, dan pengalaman.

Menurut Jakaria (1999:213) surat lamaran kerja adalah surat yang diajukan oleh seseorang untuk mendapatkan pekerja-an pada suatu instansi atau perusahaan. Surat lamaran kerja termasuk surat resmi yang bersifat pribadi. Nariyah et al., (2021) menyatakan bahwa surat lamaran pekerjaan berfungsi sebagai langkah pembuka bagi seseorang untuk bekerja di suatu tempat. Selanjutnya Seli dkk. (2021:40) mengatakan bahwa surat lamaran pekerjaan adalah surat pribadi yang bersifat resmi. Surat lamaran pekerjaan ditujukan oleh seseorang kepada lembaga atau instansi agar yang bersangkutan mendapatkan pekerjaan.

Pada umumnya, seseorang yang membutuhkan pekerjaan akan mengajukan lamaran kerja setelah mendapatkan informasi tentang adanya lowongan pekerjaan. Pratama (2000:108), menyatakan bahwa seseorang mengirim surat lamaran karena adanya permintaan/lowongan dari instansi pemerintah atau perusahaan. Lowongan pekerjaan dapat disampaikan melalui iklan, informasi dari seseorang, dan pengumuman resmi dari instansi yang membutuhkan tenaga kerja. Menurut Seli, (2021:6-7) penulisan surat lamaran pekerjaan didasarkan pada: (1) iklan, pengumuman, edaaran yang berisi informasi tentang lowongan pekerjaan dan (2) mencoba-coba.

Menurut Wijaya (1996:86) modul adalah alat ukur yang lengkap dan merupakan satu kesatuan program yang dapat mengukur tujuan. Modul sebagai paket program yang disusun dalam bentuk satuan tertentu guna keperluan belajar. Departemen Pendidikan Nasional (2002:5) mendefinisikan modul sebagai suatu kesatuan bahan belajar yang disajikan dalam bentuk selfinstruction, artinya bahan belajar yang disusun di dalam modul dapat dipelajari peserta didik secara mandiri dengan bantuan yang terbatas dari pendidik atau orang lain. Sedangkan menurut Suryosubroto (1983:17) modul adalah sebagai sejenis satuan kegiatan belajar yang terencana, didesain guna membantu peserta didik menyelesaikan tujuan tujuan tertentu.

Dengan demikian modul dapat dipahami sebagai bahan ajar terprogram yang disusun secara terpadu, sistematis, dan terperinci. Dengan modul, memberi peserta didik kesempatan untuk belajar sesuai dengan keinginan dan kemampuan. Dalam penelitian ini, modul pembelajaran digunakan untuk membantu mahasiswa dalam menulis surat dinas dan surat lamaran pekerjaan secara daring agar dapat meningkatkan kemampuan mereka dalam menulis surat dinas dan surat lamaran pekerjaan.

Modul disusun terlebih dahulu sebelum penelitian dilaksanakan. Modul tersebut berisi validasi modul; deskripsi modul; petunjuk penggunaan modul; capaian pembelajaran; teori penulisan surat yang meliputi: jenis, bagian, dan bentuk surat; surat dinas; surat lamaran pekerjaan, contoh surat dinas dan surat lamaran pekerjaaan, tugas menulis surat dinas dan surat lamaran pekerjaan; dan daftar pustaka 


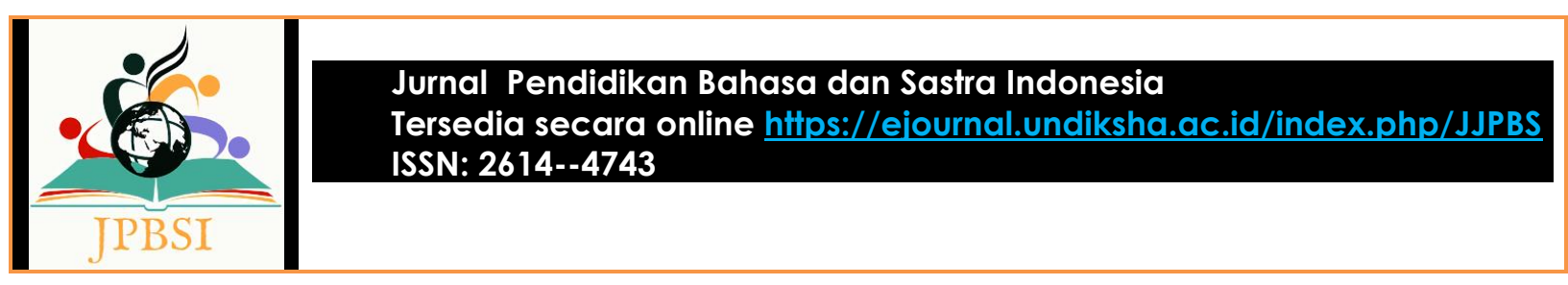

\section{METODE PENELITIAN}

Penelitian ini menggunakan metode deskriptif dengan bentuk penelitian pendekatan kuantitatif. Menurut Syamsuddin dan Damaianti (2006:24) metode deskriptif bertujuan menjelaskan fenomena yang ada dengan menggunakan angka-angka yang menggambarkan karakteristik individual atau kelompok sebagaimana adanya sesuai dengan fakta yang ada mengenai kebermanfaatan modul dalam upaya meningkatkan kemampuan menulis surat dinas dan surat lamaran pekerjaan.

Objektif kajian dalam penelitian ini meliputi kebermanfaatan modul dalam meningkatkan kemamouann menulis surat dinas dan surat lamaran pekerjaan.; kemampuan menulis surat dinas kemampuan mahasiswa menulis surat lamaran pekerjaan; kemampuan menulis surat dinas dan surat lamaran pekerjaan dengan berpandukan modul pada mahasiswa S-1 Pendidikan Bahasa Indonesia FKIP Universitas Tanjungpura.

Penarikan sampel menggunakan teknik total sampling. Sugiyono (2014:124) mengatakan bahwa total sampling adalah teknik penentuan sampel bila semua anggota populasi digunakan sebagai sampel. Sampel dalam penelitian ini adalah seluruh mahasiswa semester VII tahun akademik 2020/2021 yang yang berjumlah 22 orang.

Data penelitian dikumpulkan dengan menggunakan teknik survey dan teknik pengukuran. Kedua teknik tersebut dilakukan secara daring mengingat sedang tingginya angka penularan virus covid-19. Teknik survey merupakan suatu teknik pengumpulan informasi yang dilakukan dengan cara menyusun daftar pertanyaan yang diajukan pada responden (sampel). Dalam penelitian ini teknik survey digunakan untuk memperoleh respon dari para peserta pelatihan (sampel) berkaitan dengan ketersediaan modul pelatihan dan proses pelaksanaan pelatihan penulisan surat dinas dan surat lamaran pekerjaan yang mereka ikuti. Alat pengumpulan data yang digunakan dalam teknik survey ini adalah kuesioner. Menurut Bungin (2011:133) angket (kuesioner) adalah serangkaian daftar pertanyaan yang disusun secara sistematis, dikirimkan kepada responden untuk diisi, setelah diisi dikembalikan lai kepada peneliti. Dalam penelitian ini kuesioner tersebut dikirimkan kepada responden melalui google form pada tautan https://forms.gle/4j6VeUxWDeBawtES8).

Menurut Suyanto dan Sutinah (2007: 81) teknik pengukuran merupakan cara untuk mengetahui kualitas maupun kuantitas pengamatan atau observasi. Teknik ini menggunakan tes (soal) sebagai alat untuk memperoleh data berupa kemampuan mahasiswa dalam menulis surat dinas dan surat lamaran pekerjaan setelah mengikuti pelatihan yang diselenggarakan pada Sabtu, 5 September 2020 melalui google meet pada tautan https://meet.google.com/prn-ousz-tsq). Mahasiswa mengumpulkan surat yang mereka tulis ke e-mail peneliti sesilia.seli@fkip.untan.ac.id.

Menurut Bungin (2011:129) data adalah segala sesuatu yang hanya berhubungan dengan keterangan tentang suatu fakta dan fakta tersebut ditemukan oleh peneliti di lokasi penelitian. Merujuk pada pendapat tersebut, data dalam penelitian ini berupa jawaban mahasiswa terhadap kuesioner; kemampuan menulis surat dinas; dan kemampuan menulis surat lamaran pekerjaan.

Teknik analisis data menggunakan statistik deskriptif. Menurut Sugiyono (2009:21) statistik deskriptif adalah statistik yang digunakan untuk menggambarkan atau menganalisis suatu hasil penelitian tetapi tidak digunakan untuk membuat kesimpulan yang lebih luas. Setelah data terkumpul, dilakukan langkah-langkah berikut ini.

Menganalisis respon mahasiswa terhadap kuesioner tetang kebermanfaatan modul yang digunakan dalam penulisan surat dinas dan surat lamaran pekerjaan. Sebelum digunakan, modul divalidasi terlebih dahulu sesuai dengan format validiasi yang sudah disiapkan dengan skor maksimal 50. Kriteria validasi yang digunakan adalah sebagai berikut. 
Tabel 01. Kriteria Validasi Modul Pelatihan

\begin{tabular}{|c|c|l|}
\hline Pilihan & Rentangan Skor & \multicolumn{1}{|c|}{ Kriteria } \\
\hline 5 & $41-50$ & Sangat Layak \\
\hline 4 & $31-40$ & Layak \\
\hline 3 & $21-30$ & Kurang Layak \\
\hline 2 & $11-20$ & Tidak Layak \\
\hline 1 & $1-10$ & Sangat Tidak Layak \\
\hline
\end{tabular}

Memberikan skor terhadap surat dinas yang ditulis mahasiswa dengan kriteria sebagai berikut.

Tabel 02. Kriteria Penskoran Surat Dinas

\begin{tabular}{|l|c|}
\hline \multicolumn{1}{|c|}{ Indikator } & Skor \\
\hline Bentuk Surat & $0-10$ \\
\hline Bagian Surat & $0-20$ \\
\hline Isi Surat & $0-40$ \\
\hline Kebahasaan Surat & $0-30$ \\
\hline
\end{tabular}

Menghitung nilai kemampuan setiap mahasiswa menulis surat dinas dengan rumus sebagai berikut.

$$
\text { Nilai }=\frac{\sum \text { Skor Perolehan }}{\text { Skor Maksimal }} \times 100
$$

Memberikan skor terhadap surat lamaran pekerjaan yang ditulis maha-siswa sebagai hasil pelatihan yang diberikan dengan kriteria sebagai berikut.

Tabel 03. Kriteria Penskoran Surat Lamaran Pekerjaan

\begin{tabular}{|l|c|}
\hline \multicolumn{1}{|c|}{ Indikator } & Skor \\
\hline Bentuk Surat & $0-10$ \\
\hline Bagian Surat & $0-20$ \\
\hline Isi Surat & $0-30$ \\
\hline Kebahasaan Surat & $0-20$ \\
\hline Riwayat Hidup & $0-20$ \\
\hline
\end{tabular}

Menghitung nilai kemampuan setiap mahasiswa dalam menulis surat lamaran pekerjaan dengan rumus sebagai berikut.

$$
\text { Nilai }=\frac{\sum \text { Skor Perolehan }}{\text { Skor Maksimal }} \times 100
$$

Menghitung nilai rata-rata kemampuan menulis surat dinas dan rata-rata kemampuan menulis surat lamaran pekerjaan dengan menggunakan rumus yang dikemukan Thoifah (2015:55).

$$
\begin{gathered}
\bar{x}=\frac{\sum X}{N} \\
\text { Keterangan: } \\
\bar{x}=\text { mean (nilai rata-rata) } \\
\begin{array}{l}
\sum X=\text { jumlah nilai mahasiswa } \\
N \quad=\text { jumlah seluruh mahasiswa }
\end{array}
\end{gathered}
$$




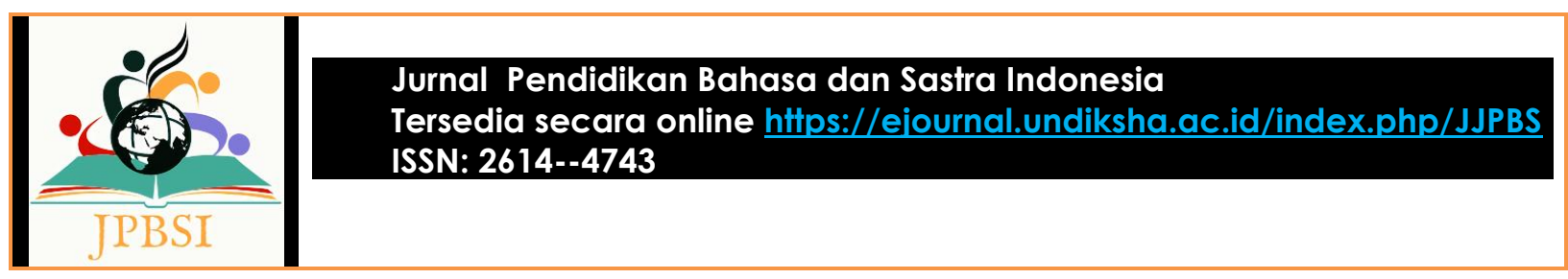

Menentukan kemampuan mahasiswa dalam menulis surat dinas dan surat lamaran pekerjaan dengan kriteria penilaian berikut ini.

Tabel 04. Kriteria Penilaian Kemampuan Menulis Surat Dinas dan Surat Lamaran Pekerjaan

\begin{tabular}{|c|c|c|}
\hline No. & Nilai Kemampuan & Kategori \\
\hline 1. & $86-100$ & Sangat Baik \\
\hline 2. & $76-85$ & Baik \\
\hline 3. & $60-75$ & Cukup \\
\hline 4. & $>60$ & Kurang \\
\hline
\end{tabular}

Modifikasi Nurgiyantoro (2016:277)

\section{HASIL DAN PEMBAHASAN}

\section{Kebermanfaatan Modul Pelatihan}

Mahasiswa semester VII Program Studi S-1 Pendidikan Bahasa Indonesia FKIP Untan dilengkapi dengan modul sebagai media dan pedoman dalam upaya meningkatkan kemampuan mereka menulis surat dinas dan surat lamaran pekerjaan. Sebelum digunakan modul terlebih dahulu divalidasi oleh Dr. A. Totok Priyadi, M.Pd. sebagai pakar media pembelajaran bahasa Indonesia dan Dr. Sisilya Saman Madeten, M.Pd. sebagai pakar Korespondensi Bahasa Indonesia. Hal ini sesuai dengan pendapat Al Azka et al (2019:231) yang mengatakan bahwa validasi ahli dibutuhkan untuk menilai kelayakan media (modul) yang digunakan. Validator yang dipilih yaitu ahli yang berkompeten dan mengerti sesuai bidangnya masing-masing. Hal yang sama juga dinyatakan oleh Nesri dan Kristanto (2020:483) bahwa validasi modul digunakan untuk mengukur validitas dari modul yang dikembangkan dan dilakukan oleh ahli materi dan ahli media.

Dalam penelitian ini, kedua pakar masing-masing memberikan skor yang tidak jauh berbeda, yaitu 47 (94\%) dan 46 (92\%. Apabila dibandingkan dengan kriteria yang telah direntukan peneliti, maka nilai tersebut berada pada kategori sangat layak yaitu pada rentangan nilai 41-50. Dengan demikian modul tersebut sangat layak digunakan sebagai media dan bahan ajar dalam praktik penulisan surat tersebut.

Untuk mengetahui respons mahasiswa terhadap kebermanfaatan modul, disebarkanlah kuesioner secara daring melalui google form pada tautan https://forms.gle/ 4j6VeUxWDeBawtES8. Praktik menulis surat berpandukan modul ini diikuti oleh 22 orang peserta yang terdiri atas 2 orang laki-laki $(9,1 \%)$ dan 20 orang perempuan $(90,9 \%)$. Praktik penulisan surat ini bersifat sukarela, oleh sebab itu tidak semua mahasiswa semester VII Prodi Program Sarjana Pendidikan Bahasa Indonesia, ambil bagian, hanya mereka yang bersedia saja yang mengikutinya.

Tabel 05. Kebermanfaatan Modul Penulisan Surat Dinas dan Surat Lamaran Pekerjaan

\begin{tabular}{|c|c|c|c|}
\hline \multirow{2}{*}{ Pernyataan } & \multicolumn{3}{|c|}{ Jumlah Responden } \\
\cline { 2 - 4 } & Netral & Setuju & Sangat Setuju \\
\hline$K-1$ & 0 & $4(18,2 \%)$ & $18(81,8 \%)$ \\
\hline$K-2$ & 0 & $10(45,5 \%)$ & $12(54,5 \%)$ \\
\hline$K-3$ & 0 & $4(18,2 \%)$ & $18(81,8 \%)$ \\
\hline$K-4$ & 0 & $4(18,2 \%)$ & $18(81,8 \%)$ \\
\hline$K-5$ & 0 & $2(9,1 \%)$ & $20(90,9 \%)$ \\
\hline$K-6$ & 0 & $9(40,9 \%)$ & $13(59,1 \%)$ \\
\hline$K-7$ & 0 & $11(50,0 \%)$ & $11(50,0 \%)$ \\
\hline$K-8$ & 0 & $9(40,9 \%)$ & $13(59,1 \%)$ \\
\hline$K-9$ & 0 & $10(45,5 \%)$ & $12(54,5 \%)$ \\
\hline
\end{tabular}




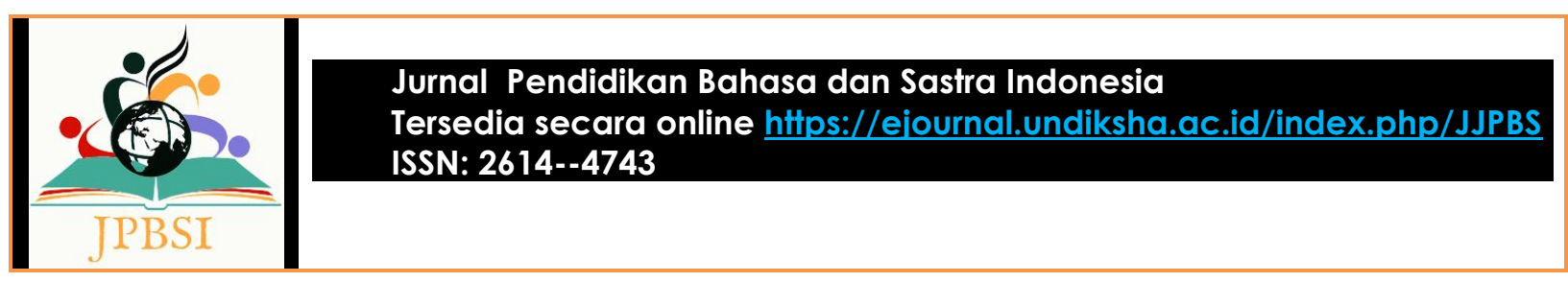

\begin{tabular}{|c|c|c|c|}
\hline$K-10$ & 0 & $5(22,7 \%)$ & $17(77,3 \%)$ \\
\hline$K-11$ & 0 & $12(54,5 \%)$ & $10(45,5 \%)$ \\
\hline$K-12$ & 0 & $13(59,1)$ & $9(40,9 \%)$ \\
\hline$K-13$ & 0 & $4(18,2 \%)$ & $18(81,8 \%)$ \\
\hline$K-14$ & 0 & $12(54,5 \%)$ & $10(45,5 \%)$ \\
\hline$K-15$ & $1(4,5 \%)$ & $8(41,0 \%)$ & $13(54,5 \%)$ \\
\hline$K-16$ & $1(4,5 \%)$ & $12(54,5 \%)$ & $9(41,0 \%)$ \\
\hline$K-17$ & 0 & $7(31,8 \%)$ & $15(68,2 \%)$ \\
\hline$K-18$ & 0 & $6(27,3 \%)$ & $16(72,7 \%)$ \\
\hline$K-19$ & 0 & $4(18,8 \%)$ & $18(81,8 \%)$ \\
\hline$K-20$ & 0 & $3(13,6 \%)$ & $19(86,4 \%)$ \\
\hline \multirow{2}{*}{ Rerata } & 0,1 & 7,45 & 14,45 \\
\cline { 2 - 4 } & $0,5 \%$ & $33,8 \%$ & $65,7 \%$ \\
\hline
\end{tabular}

Kuesioener berisi 20 pernyataan dengan lima pilihan, yakni sangat setuju, setuju, netral, tidak setuju, dan sangat tidak setuju. Karena pilihan responden hanya tiga jenis, maka yang ditampilkan pada tabel di atas hanya tiga pilihan yang dipilih oleh responden. Sebanyak 72,7\% responden mengatakan sangat setuju dan $27,3 \%$ setuju dengan pernyataan bahwa modul memuat secara lengkap informasi yang diperlukan; memuat tujuan pembelajaran yang mencakup aspek sikap, pengetahuan, dan keterampilan; serta disajikan secara teratur dan sistematis.

Pada umumnya responden sangat setuju $(62,1 \%)$ dan setuju $(37,9 \%)$ dengan pernyataan bahwa teori tentang jenis surat yang disajikan sesuai dengan harapan dan kebutuhan responden; teori tentang bagian-bagian surat disajikan dengan sistematis dengan memberikan contoh secara tepat; dan bagan bentuk-bentuk surat yang menunjukkan bagian-bagian surat dapat dipahami dengan baik.

Sebanyak 54,5\% responden sangat setuju dan $45,5 \%$ responden setuju dengan pernyataan bahwa responden dapat mem-bedakan setiap bentuk-bentuk surat yang disajikan; dapat memahami teori surat dinas dengan baik; dan dapat memahami dengan baik paparan setiap jenis surat dinas yang ada di dalam modul.

Pada umumnya responden menyatakan sangat setuju $(54,5 \%)$ dan setuju $(45,5 \%)$ dengan pernyataan bahwa contoh surat dinas yang disediakan dalam modul menambah wawasan dan pengetahuan mereka; modul menyajikan contoh surat dinas yang menggunakan berbagai bentuk surat; dan responden dapat membedakan penulisan surat dinas yang menggunakan bentuk surat berperihal dan surat berjudul.

Sebanyak 56,8\% responden menyatakan sangat setuju, 40,9\% setuju, dan 3,3\% netral terhadap pernyataan bahwa teori surat lamaran pekerjaan sangat dibutuhkan oleh responden; penulisan surat lamaran pekerjaan sebaiknya menggunakan bentuk surat berperihal; penulisan surat lamaran pekerjaan dapat dilakukan dengan menggunakan tulisan tangan dan dapat pula menggunakan komputer; dan contoh surat lamaran pekerjaan dalam moduk menggunakan bentuk setengah lurus.

Sebagain besar responden menyatakan sangat setuju (70,5\%) dan setuju $(29,5 \%)$ dengan pernyataan bahwa modul yang digunakan untuk menyampaikan materi dalam rangka meningkatkan kemampuan menulis surat dinas dan surat lamaran pekerjaan yang disampaikan secara daring. Pada umunya responden sangat setuju $(84,1 \%)$ dan setuju $(15,9 \%)$ dengan pernyataan bahwa materi penulisan surat dinas dan surat lamaran pekerjaan bermanfaat untuk memasuki dunia kerja dan penulisan surat dinas dan surat lamaran pekerjaan melatih keterampilan produktif dalam berbahasa.

Berdasarkan analisis dan pembahasan terhadap kuesioner dalam penelitian ini dapat disimpulkan bahwa modul yang disusun sebagai sebagai media untuk praktik menulis surat dinas dan surat lamaran pekerjaan secara daring sangat bermanfaat bagi mahasiswa. Hal ini terbukti dengan 


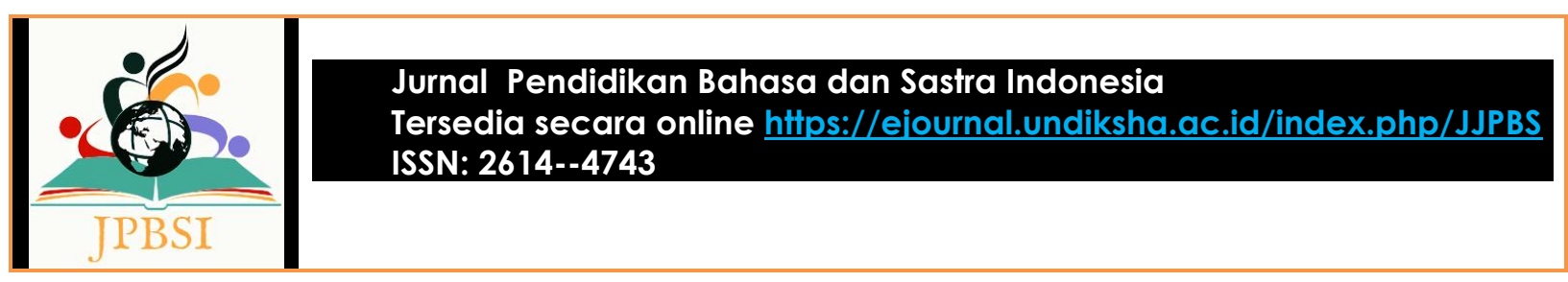

sebagian besar responden menyatakan sangat setuju $(65,7 \%)$; setuju ( $33,8 \%)$; dan yang menyatakan netral sebesar $0,5 \%$.

Respons yang berkaitan dengan kebermanfaat modul dalam praktik penulisan surat dinas dan surat lamaran pekerjaan menunjukkan bahwa modul sebagai media pembelajaran dapat membantu mahasiswa untuk memahami konsep tentang surat dinas dan surat lamaran pekerjaan sehingga dapat mempraktikkannya dalam hidup sehari-hari. Dengan demikian modul seperti yang dikatakan Mufidah (2014:8) merupakan bahan ajar yang disusun secara utuh, sistematis dan menarik dengan bahasa yang mudah dimengerti oleh peserta didik sesuai dengan tingkat kemampuannya, agar peserta didik tersebut dapat lebih mendalami materi pembelajaran serta indikator pencapaian hasil belajar yang spesifik, bersifat mandiri sehingga dapat memudahkan peserta didik untuk belajar sendiri sesuai dengan kemampuannya tanpa bantuan guru

\section{Kemampuan Menulis Surat Dinas}

Kemapuan mahasiswa dalam menulis surat dinas setelah mengikuti pelatihan secara daring dideskripsikan pada tabel berikut ini.

Tabel 06. Kemampuan Menulis Surat Dinas

\begin{tabular}{|c|c|c|c|c|c|}
\hline \multirow{2}{*}{ Sampel } & \multicolumn{4}{|c|}{ Skor Aspek yang Dinilai } & \multirow{2}{*}{ Nilai } \\
\hline & 10 & 20 & 40 & 30 & \\
\hline$M-1$ & 10 & 18 & 36 & 22 & 86 \\
\hline$M-2$ & 8 & 15 & 34 & 21 & 78 \\
\hline$M-3$ & 7 & 17 & 33 & 21 & 78 \\
\hline$M-4$ & 10 & 16 & 36 & 24 & 86 \\
\hline$M-5$ & 9 & 16 & 34 & 23 & 82 \\
\hline$M-6$ & 10 & 20 & 36 & 26 & 92 \\
\hline$M-7$ & 9 & 18 & 36 & 23 & 86 \\
\hline$M-8$ & 8 & 17 & 36 & 23 & 84 \\
\hline$M-9$ & 8 & 18 & 34 & 22 & 82 \\
\hline$M-10$ & 10 & 20 & 37 & 27 & 94 \\
\hline$M-11$ & 8 & 18 & 35 & 23 & 84 \\
\hline$M-12$ & 9 & 18 & 35 & 23 & 85 \\
\hline$M-13$ & 10 & 19 & 38 & 27 & 94 \\
\hline$M-14$ & 8 & 15 & 35 & 20 & 78 \\
\hline$M-15$ & 7 & 15 & 34 & 19 & 75 \\
\hline$M-16$ & 7 & 16 & 33 & 19 & 75 \\
\hline$M-17$ & 8 & 18 & 34 & 20 & 80 \\
\hline$M-18$ & 10 & 20 & 37 & 25 & 92 \\
\hline$M-19$ & 8 & 15 & 34 & 21 & 78 \\
\hline$M-20$ & 8 & 18 & 33 & 23 & 82 \\
\hline$M-21$ & 8 & 18 & 34 & 24 & 84 \\
\hline$M-22$ & 9 & 18 & 36 & 22 & 85 \\
\hline Rerata & 8,6 & 17,4 & 35 & 22,6 & 83,6 \\
\hline
\end{tabular}

Berdasarkan hasil perhitungan terhadap kemampuan mahasiswa Prodi S-1 Pendidikan Bahasa Indonesia dalam menulis surat dinas diketahui bahwa ada dua orang mahasiswa $(9,1 \%)$ mendapatkan nilai terendah yaitu 75 dan dua orang mahasiswa (9.1\%) mendapatkan nilai tertinggi yaitu 94 .

Data menunjukkan bahwa ada 9 mahasiswa $(40,9 \%)$ mendapatkan nilai rata-rata 88,9 . Nilai tersebut berada pada rentangan 86-100 dengan ketegori sangat baik. Selebihnya 13 mahasiswa $(59,1 \%)$ mendapat nilai rata-rata 80, berada pada rentangan $76-85$ dengan kategori baik. 


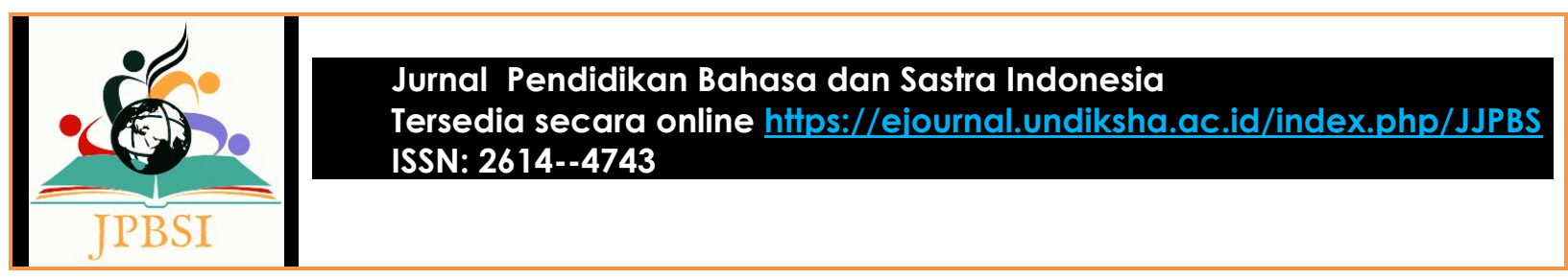

Memperhatikan kriteria penilaian yang digunakan diperoleh hasil bahwa rata-rata skor mahasiswa yang menunjukkan kemampuan: (a) menggunakan bentuk surat sebesar 8,6 (86\%); (b) ketepatan menempatkan bagian-bagian surat sebesar 17,4 (87,1\%); (c) menulis isi surat dinas sebesar 35 (87,5\%); dan (d) menggunakan kebahasaan surat (diksi, kalimat, dan ejaan) sebesar 22,6 (75,5\%).

Mencermati hasil perhitungan tersebut, aspek kebahasaan surat yang terdiri atas diksi, kalimat, dan ejaan mendapat rata-rata prosentase terendah $(75,5 \%)$ dari empat aspek yang dinilai. Hal ini menunjukkan bahwa ketelitian dan kecermatan dalam menerapkan ejaan, pilihan kata, dan penggunaan kalimat efektif masih harus ditingkatkan. Penelitian terhadap penulisan surat dinas yang dilakukan oleh Prasetya (2019) di STKIP Al Hikmah Surabaya juga menunjukkan hal yang sama bahwa masih terdapat kesalahan ejaan berupa penggunaan huruf kapital, tanda koma, tanda titik dua, dan pilihan kata. Menurut Yulianti, Fajrin, dan Happe (2020) dalam penelitiannya terhadap penulisan surat dinas, yang menjadi faktor penyebab terjadinya kesalahan tersebut adalah kekurangpahaman terhadap aturan bahasa Indonesia; ketidaksengajaan pemakaian bahasa; faktor lingkungan; dan faktor bahasa yang mencakup kesulitan berbahasa dan pengaruh bahasa daerah.

Kemampuan mahasiswa dalam menggunakan bentuk surat, ketepatan menempatkan bagianbagian surat, dan menulis isi surat dinas rata-rata $86,8 \%$. Hal ini menunjukkan kemampuan yang terkategori sangat baik. Hal yang sama juga ditunjukkan oleh hasil penelitian yang dilakukan oleh Susilo, Pujiatna, dan Firmasari (2020:176) bahwa perangkat desa Mandala dapat menggunakan tata bentuk dan bahasa surat sesuai dengan kaidah penulisan bahasa surat dan standar bentuk surat.

Namun, secara umum dapat disimpulkan bahwa nilai rata-rata kemampuan mahasiswa menulis surat dinas sebesar 83,6. Nilai rata-rata tersebut berada pada rentangan 76-85. Apabila dibandingkan dengan kriteria yang telah ditetapkan maka rata-rata kemampuan menulis surat dinas berada pada kategori baik. Dengan demikian praktik menulis surat dinas berpandukan modul yang dilakukan secara daring dapat dikatakan berhasil dengan baik.

\section{Kemampuan Menulis Surat Lamaran Pekerjaan}

Berikut dipaparkan kemampuan mahasiswa menulis surat lamaran pekerjaan setelah mengikuti pelatihan secara daring.

Tabel 07. Kemampuan Menulis Surat Lamaran Pekerjaan

\begin{tabular}{|c|c|c|c|c|c|c|}
\hline \multirow{2}{*}{ Sampel } & \multicolumn{5}{|c|}{ Skor Aspek yang Dinilai } & \multirow{2}{*}{ Nilai } \\
\hline & 10 & 20 & 30 & 20 & 20 & \\
\hline$M-1$ & 9 & 18 & 28 & 17 & 18 & 90 \\
\hline$M-2$ & 9 & 18 & 28 & 17 & 18 & 90 \\
\hline$M-3$ & 8 & 16 & 26 & 16 & 18 & 84 \\
\hline$M-4$ & 7 & 15 & 24 & 15 & 14 & 75 \\
\hline$M-5$ & 8 & 18 & 28 & 18 & 18 & 90 \\
\hline$M-6$ & 8 & 15 & 24 & 16 & 17 & 80 \\
\hline$M-7$ & 10 & 18 & 28 & 18 & 19 & 93 \\
\hline$M-8$ & 7 & 14 & 24 & 15 & 15 & 75 \\
\hline$M-9$ & 7 & 13 & 24 & 16 & 15 & 75 \\
\hline$M-10$ & 8 & 17 & 28 & 18 & 19 & 90 \\
\hline$M-11$ & 10 & 18 & 28 & 18 & 18 & 92 \\
\hline$M-12$ & 8 & 16 & 26 & 16 & 16 & 82 \\
\hline$M-13$ & 8 & 18 & 26 & 18 & 17 & 87 \\
\hline$M-14$ & 9 & 18 & 28 & 19 & 20 & 94 \\
\hline$M-15$ & 9 & 17 & 26 & 16 & 17 & 85 \\
\hline$M-16$ & 8 & 16 & 28 & 16 & 18 & 86 \\
\hline$M-17$ & 10 & 20 & 28 & 18 & 18 & 94 \\
\hline
\end{tabular}




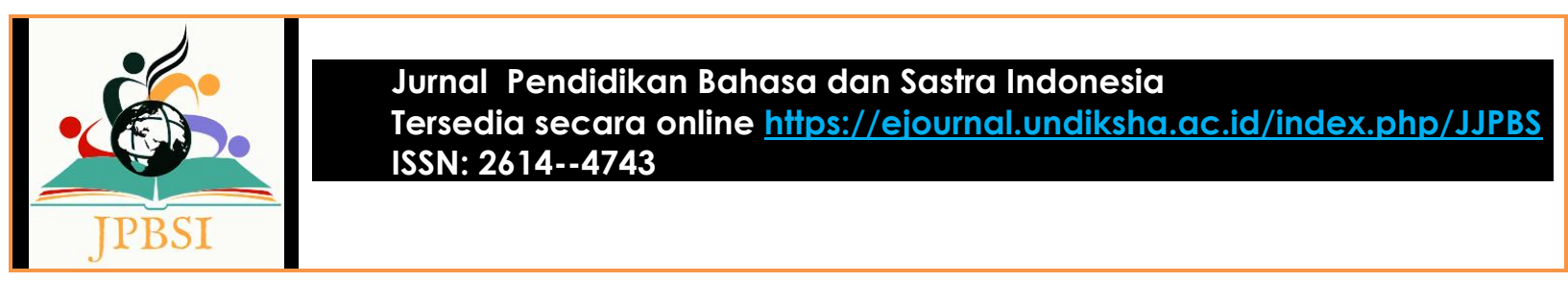

\begin{tabular}{|c|c|c|c|c|c|c|}
\hline$M-18$ & 7 & 15 & 24 & 16 & 16 & 78 \\
\hline$M-19$ & 10 & 19 & 29 & 18 & 18 & 94 \\
\hline$M-20$ & 8 & 18 & 26 & 16 & 17 & 85 \\
\hline$M-21$ & 8 & 18 & 27 & 16 & 17 & 86 \\
\hline$M-22$ & 7 & 15 & 24 & 16 & 16 & 78 \\
\hline Rerata & 8,3 & 16,8 & 26,5 & 16,7 & 17,1 & 85,4 \\
\hline
\end{tabular}

Berdasarkan hasil perhitungan terhadap kemampuan mahasiswa Prodi S-1 Pendidikan Bahasa Indonesia dalam menulis surat lamaran pekerjaan diketahui bahwa ada empat orang mahasiswa $(18,2 \%)$ mendapatkan nilai terendah yaitu 75 dan dua orang mahasiswa $(9.1 \%)$ mendapatkan nilai tertinggi yaitu 94 .

Data menunjukkan bahwa ada 14 mahasiswa $(63,6 \%)$ mendapatkan nilai rata-rata 89,4 . Nilai tersebut berada pada rentangan 86-100 dengan ketegori sangat baik. Selebihnya 8 mahasiswa $(36,4 \%)$ mendapat nilai rata-rata 78 , berada pada rentangan 76-85 dengan kategori baik.

Memperhatikan kriteria penilaian yang digunakan diperoleh hasil bahwa rata-rata skor mahasiswa yang menunjukkan kemampuan: (a) menggunakan bentuk surat sebesar 8,3 (82,7\%); (b) ketepatan menempatkan bagian-bagian surat sebesar 16,8 (84,1\%); (c) menulis isi surat lamaran pekerjaan sebesar 26,1 (88,1\%); (d) menggunakan kebahasaan surat (diksi, kalimat, dan ejaan) sebesar 16,7 (83,6\%); dan menulis riwayat hidup sebesar 17,1 (85,7\%). Meskipun rata-rata skor yang diperoleh terkategori baik, namum kemampuan menggunakan bentuk surat memperoleh prosentase terendah $(82,7 \%)$. Perlu dilakukan praktik yang terus-menerus agar terbentuk kebiasaan dan kecermatan dalam menggunakan bentuk surat. Selain itu, masih ditemukan kesalahan dalam penulisan alamat surat, meskipun jumlahnya tidak banyak. Contoh kesalahan yang dimaksud adalah masih digunakannya kata kepada pada alamat surat yang seharusnya cukup menggunakan kata yang terhormat (Yth.). Kesalahan lainnya adalah kesalahan penulisan kata yang tidak sesuai dengan ejaan yang berlaku. Berkaiatan dengan kesalahan tersebut, dalam penelitian yang lain, Sari dan Dinihari (2020:291) juga menemukan kesalahan-kelsalahan yang sama. Mereka menyimpulkan bahwa kesalahan paling banyak dilakukan siswa adalah kesalahan ejaan (90\%). Hal ini disebabkan karena siswa belum mengerti dan belum paham penulisan ejaan yang sesuai dengan Pedoman Umum Ejaan Bahasa Indonesia dan Kamus Besar Bahasa Indonesia. Kesalahan yang berkaitan dengan ejaan yang dilakukan mahasiswa dalam penelitian ini disebabkan oleh kekurangancermatan dan kekurangtelitian mahasiswa yang bersangkutan.

Dari empat kriteria yang digunakan untuk menilai dan menganalisis kemampuan menulis surat lamaran pekerjaan, kemampuan menulis isi surat lamaran pekerjaan menempati hasil tertinggi yaitu 26,1 $(88,1 \%)$. Hal ini menunjukkan bahwa mahasiswa sudah dapat mengungkapkan secara sistematis isi surat lamaran pekerjaan sesuai dengan tujuan penulisan surat tersebut. Hal yang sama juga ditunjukkan oleh hasil penelitian yang dilakukan oleh Naryah, Arifin, dan Ariesta (2021: 35) bahwa rata-rata kemampuan menulis surat lamaran kerja siswa berdasarkan aspek kesesuaian isi surat adalah 32,67 dengan kategori sangat baik. Rata-rata kemampuan menulis surat lamaran kerja siswa berdasarkan aspek sistematika surat adalah 26,38 dengan kategori sangat baik. Rata-rata kemampuan menulis surat lamaran kerja siswa berdasarkan aspek kebahasaan adalah 15,17 dengan kategori baik.

Mencermati hasil perhitungan tersebut, semua aspek yang dinilai menunjukkan bahwa kemampuan rata-rata mahasiswa di atas $80 \%$. Hal ini menunjukkan bahwa praktik yang berpandukan modul dapat membantu mahasiswa meningkatkan kemampuannya dalam menulis surat lamaran pekerjaan. Hal tersebut diisebabkan oleh tersedianya contoh dalam modul yang dapat dijadikan contoh pada saat mereka menulis surat lamaran pekerjaan. Sebab pada hakikatnya modul merupakan seperangkat bahan ajar yang ditulis secara sistematis, sehingga penggunanya dapat belajar dengan atau tanpa seorang guru (Prastowo, 2012:104). 


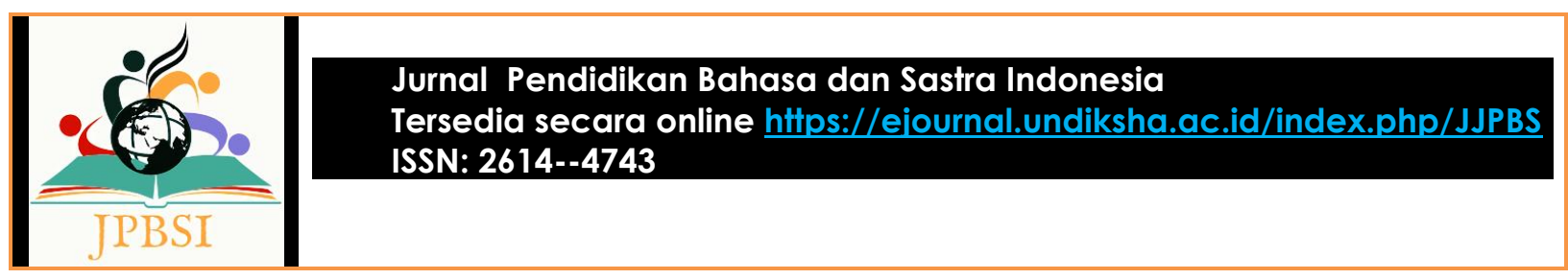

Secara umum dapat disimpulkan bahwa nilai rata-rata kemampuan maha-siswa menulis surat lamaran pekerjaan sebesar 85,4. Nilai rata-rata tersebut berada pada rentangan 76-85. Apabila dibandingkan dengan kriteria yang telah ditetapkan maka rata-rata kemampuan menulis surat lamaran pekerjaan berada pada kategori baik. Dengan demikian praktik menulis surat lamaran pekerjaan yang dilaksanakan secara daring dapat dikatakan berhasil dengan baik.

\section{Kemampuan Menulis Surat Dinas dan Surat Lamaran Pekerjaan}

Tabel 08. Kemampuan Menulis Surat Dinas dan Surat Lamaran Pekerjaan

\begin{tabular}{|c|c|c|c|}
\hline Sampel & Nilai Surat Dinas & $\begin{array}{c}\text { Nilai Surat Lamaran } \\
\text { Pekerjaan }\end{array}$ & Rerata Nilai \\
\hline$M-1$ & 86 & 90 & 88 \\
\hline$M-2$ & 78 & 84 & 81 \\
\hline$M-3$ & 78 & 75 & 76,5 \\
\hline$M-4$ & 86 & 90 & 88 \\
\hline$M-5$ & 82 & 80 & 81 \\
\hline$M-6$ & 92 & 93 & 92,5 \\
\hline$M-7$ & 86 & 75 & 80,5 \\
\hline$M-8$ & 84 & 75 & 79,5 \\
\hline$M-9$ & 82 & 90 & 86 \\
\hline$M-10$ & 94 & 92 & 93 \\
\hline$M-11$ & 84 & 82 & 83 \\
\hline$M-12$ & 85 & 87 & 86 \\
\hline$M-13$ & 94 & 94 & 94 \\
\hline$M-14$ & 78 & 85 & 81,5 \\
\hline$M-15$ & 75 & 86 & 80,5 \\
\hline$M-16$ & 75 & 94 & 84,5 \\
\hline$M-17$ & 80 & 78 & 79 \\
\hline$M-18$ & 92 & 94 & 93 \\
\hline$M-19$ & 78 & 85 & 81,5 \\
\hline$M-20$ & 82 & 86 & 84 \\
\hline$M-21$ & 84 & 78 & 81 \\
\hline$M-22$ & 85 & 86 & 85,5 \\
\hline Rerata & 83,6 & 85,4 & 84,5 \\
\hline
\end{tabular}

Berdasarkan hasil perhitungan terhadap kemampuan mahasiswa Prodi S-1 Pendidikan Bahasa Indonesia dalam menulis surat dinas dan surat lamaran pekerjaan diketahui bahwa ada satu orang mahasiswa $(9,1 \%)$ mendapatkan nilai terendah yaitu 76,5 dan satu orang mahasiswa $(9.1 \%)$ mendapatkan nilai tertinggi yaitu 94 .

Data menunjukkan bahwa ada 10 mahasiswa (45,5\%) mendapatkan nilai rata-rata 89,1 . Nilai tersebut berada pada rentangan 86-100 dengan ketegori sangat baik. Selebihnya 12 mahasiswa $(54,5 \%)$ mendapat nilai rata-rata 80,8, berada pada rentangan $76-85$ dengan kategori baik.

Secara umum dapat disimpulkan bahwa nilai rata-rata kemampuan maha-siswa menulis surat dinas dan surat lamaran pekerjaan sebesar 84,5. Nilai rata-rata tersebut telah melampaui rentangan 76-85. Dengan demikian dapat disimpulkan bahwa kemampuan menulis surat dinas dan surat lamaran pekerjaan berada pada kategori baik. Berdasarkan data tersebut dapat dikatakan bahwa pelatihan menulis surat dinas dan surat lamaran pekerjaan yang dilengkapi dengan modul peletihan dan dilaksanakan secara daring berhasil dengan baik. 


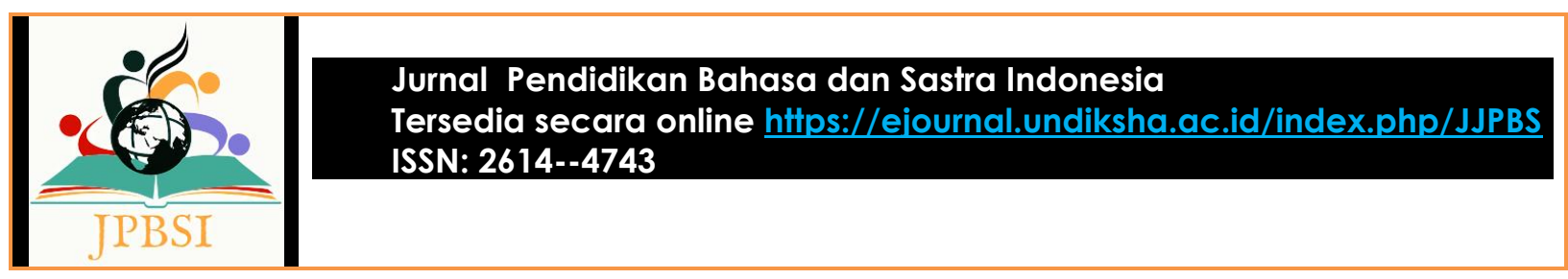

PENUTUP

Kebermanfaatan modul yang digunakan dalam praktik menulis surat dinas dan surat lamaran pekerjaan secara daring sangat dirasakan oleh para responden. Hal ini terbukti dengan respon yang mereka berikan. Sebanyak $65,7 \%$ responden menyatakan sangat setuju, 33,8\% responden setuju; dan 33,8\% responden bersikap netral terhadap 20 pernyataan yang ada di dalam kuesioner. Nilai ratarata kemampuan mahasiswa menulis surat dinas sebesar 83,6. Nilai rata-rata tersebut berada pada rentangan 75-84. Apabila dibandingkan dengan kriteria yang telah ditetapkan maka rata-rata kemampuan menulis surat dinas berada pada kategori baik. Nilai rata-rata kemampuan mahasiswa menulis surat lamaran pekerjaan sebesar 85,4. Nilai rata-rata tersebut berada pada rentangan 76-85. Apabila dibandingkan dengan kriteria yang telah ditetapkan maka rata-rata kemampuan menulis surat lamaran pekerjaan berada pada kategori baik. Nilai rata-rata kemampuan mahasiswa menulis surat dinas dan surat lamaran pekerjaan sebesar 84,5. Nilai rata-rata tersebut berada pada rentangan 76-85. Dengan demikian dapat disimpulkan bahwa kemampuan menulis surat dinas dan surat lamaran pekerjaan berada pada kategori baik. Berdasarkan hasil analisis dan pembahasan dapat disimpulkan bahwa praktik menulis surat dinas dan surat lamaran pekerjaan yang dilengkapi dengan modul dan dilaksanakan secara daring berhasil dengan baik.

\section{DAFTAR PUSTAKA}

Al Azka, et al. (2019). Pengembangan Modul Pembelajaran. Imajiner: Jurnal Matematika dan Pendidikan Matematik. Vol.1, No. 5, September 2019, p.224-236. journal. upgris.ac.id/ index.php/imajiner.

Bungin, B. (2011). Metodologi Penelitian Kuantitatif: Komunikaksi, Ekonomi,, dan Kebijakan Publik serta Ilmu-ilmu Sosial Lainnya. Jakarta: Kencana Prenada Media Group.

Finoza, Lamuddin. (1997). Aneka Surat Sekretaris dan Bisnis Indonesia. Jakarta: Mawar Gempita. Gaizani, Z.D. Nabila. (2003). Jurus Cepat Menulis Surat Lamaran. Yogyakarta: Penerbit Absolut. Jakaria, I. (1999). Multipurpose Letter. Bandung: CV Pustaka Setia.

Kementerian Pendidikan dan Kebudayaan. (2017). Buku Siswa Bahasa Indonesia SMA/MA/SMK/MAN Kelas XII. Jakarta: Kementerian Pendidikan dan Kebudayaan.

Mufidah, C.I. 2014. Pengembangan Modul Pembelajaran pada Kompetensi Dasar Hubungan Masyarakat Kelas X Apk 2 di SMK N 10 Surabaya. https://ejournal.unesa.ac.id > jpap > article > view.

Nadia, Faizatin dan Sugihastuti. (2018). Surat Dinas: Teori dan Paraktik. Yogyakarta: Pustaka Pelajar.

Nariyah, Ahlun, M. Arifin, dan Ria Ariesta (2021). Kemampuan Menulis Surat Lamaran Kerja Berdasarkan Iklan Siswa Kelas XII SMk Negeri 2 Kota Bengkulu. Jurnal Ilmiah Korpus Vol. 5 No. 1. p. 35-44. doi: https://doi.org/ 10.33369/jik.v5i1.13414

Nesri, F.D.P dan Kristanto, Y.D. (2020). Pengembangan Modul Ajar Berbantuan Teknologi Untuk Mengembangkan Kecakapan Abad 21 Siswa. AKSIOMA: Jurnal Program Studi Pendidikan Matematika. Vol. 9, No. 3, 2020, p. 480-492. DOI: https://doi.org/10.24127/ajpm.v9i3.2925

Nurgiyantoro, B. (2016). Penilaian dan Pengajaran Bahasa Berbasis Kompetensi . Yogyakarta: BPFE.

Prasetya, A. D. A. (2019). Analisis Kesalahan Ejaan dan Pilihan Kata pada Surat Dinas di STKIP Al Hikmah Surabaya. Lingua Franca:Jurnal Bahasa, Sastra, Dan Pengajarannya, 3(1), 120. https://doi.org/10.30651/lf.v3i1.2377.

Prastowo, Andi. (2012). Panduan Kreatif Membuat Bahan Ajar Inovatif. Yogyakarta: Diva Press. Pratama, A. (2000). Teknik Menulis Surat Menyurat Lengkap. Yogyakarta: Bintang Cemerlang.

Putri, Arum Sutrisni. (2020). Pengertian Surat Lamaran Pekerjaan. Online. https://www.kompas.com/skola/read/2020/09/15/182010669/pengertian-surat-lamaranpekerjaan?page=all. Diakses 10 Oktober 2020. 


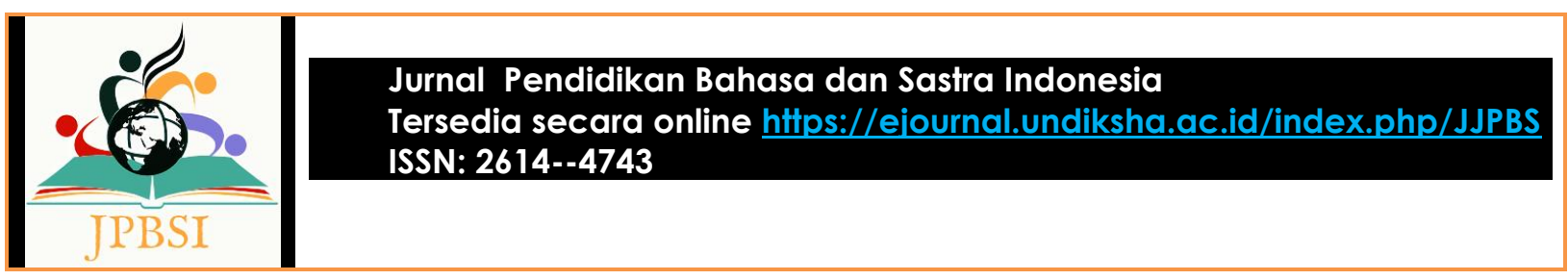

Rohmadi, dkk. (2014). Belajar Bahasa Indonesia. Surakarta: Cakrawala Media.

Saraswati, I. 2015. Mahir Membuat Surat Dinas dalam Sekejap: Panduan Lengkap Membuat Aneka Surat Dinas. Yogyakarta: Laksana.

Sari dan Dinihari. (2020). Analisis Kesalahan Berbahasa dalam Penulisan Surat Lamaran Pekerjaan. Prosiding Seminar Nasional dan Diskusi Panel Pendidikan Matematika Universitas Indraprasta PGRI, Jakarta, 291-298.

Seli, Sesilia. dkk. (2021). Modul Workshop Penulisan Surat Dinas dan Surat Lamaran Pekerjaan. Pontinak: Pustaka Rumah Aloy.

Soedjito dan Solichin, T.W. 2016. Surat Menyurat Resmi Indonesia. Bandung: PT Remaja Rosdakarya.

Sotyaningrum, A.T. (2008). Korespndensi Bahasa Indonesia Dasar, Teori, dan Aplikasi. Yogyakarta: Amara Books

Sudarsa, Caca, dkk. (1992). Surat Menyurat Dalam Bahasa Indonesia. Jakarta: Pusat Pembinaan dan Pengembangan Bahasa.

Sugiyono. (2009). Statistik untuk Penelitian. Banding: Alfabeta.

Sugiyono. (2014). Metode Penelitian Bisnis (Pendekatan Kuantitatif, Kualitatif, dan R\&D). Bandung: Alfabeta.

Suprapto.2014. Penuntun Praktis Surat Menyurat Dinas Resmi Bahasa Indonesia. Bandung: CV Mandar Maju.

Supriyana, Asep, dkk. (2015). Pelatihan Penggunaan Ejaan Yang Disempurnakan dan Kalimat Efektif pada Penulisan Surat Resmi bagi Guru Sekolah Dasar di Jakarta Timur. Jurnal Sarwahita. Vol 12 No $1:$ hal 1-12.

Suryaman, Maman., Suherli., dan I. (2018). Buku Guru: Bahasa Indonesia untuk SMA/MA/SMK/MAK Kelas XII (M. R. Purnanto, Dwi. (ed.); Ke-2). Kementerian Pendidikan dan Kebudayaan.

Suryosubroto, B. (1983). Sistem Pengajaran dengan Modul. Jakarta: Bina Aksara.

Susilo, J., Pujiatna, T., Firmasari, S. (2020). Pembinaan Tata Bahasa dan Bentuk Surat-Menyurat Indonesia Berbasis Microsoft di Desa Mandala, Dukupuntang, Kabupaten Cirebon. JPPM LPIMP UMP Volume 4, No. 1 Maret 2020, 173-177. JPPM ISSN: 2549 - 8347

Suyanto, G. Sutinah (Ed.). (2007). Metode Penelitian Sosial: Berbagai Alternatif Pendekatan. Jakarta: Kencana Prenada Media Group

Syamsudin dan Vismaia S. Damianti. (2006). Metode Penelitian Pendidikan Bahasa. Bandung: UPIPT Remaja Rosdakarya.

Thoifah, I. (2015). Statistika Pendidikan dan Metode Penelitian Kuantitatif. Malang: Madani.

Triyatna, S. (2014). Korespondensi Bahasa Indonesia untuk Perguruan Tinggi. Yogyakarta: Mediatera.

Wijaya, Cece. (1992). Upaya Pembaharuan dalam Pendidikan dan Pengajaran. Bandung: Remaja Rosdakarya,

Yulianti A. I., Fajrin H., Happe A, (2020). Penggunaan Ejaan dalam Surat Dinas di Polres Bulukumba. Kibas Cenderawasih. DOI:https://doi.org/10.26499/kc.v17i1.236

Copyright holder: @ Seli, S. \& Anggih, Z. (2021)

Fist publication right: Jurnal Pendidikan Bahasa dan Sastra Indonesia Undiksha 